\title{
THE INFLUENCE OF THE USE THE FIRST LANGUAGE IN INDONESIAN EFL CLASSROOMS
}

\author{
Ida Nuraida \\ idanuraida@unbaja.ac.id \\ Universitas Banten Jaya
}

\begin{abstract}
Despite widespread use only English in Teaching EFL, the use of first language in EFL class has been a perennial topic of discussion in the field of language education. Most established L2 teaching methods discourage the use of L1 in class. This research attempt to explore the use of first language in Indonesian in the EFL Classroom as well as lecturer and students response toward it. The presents study aimed to find out how the lecturer view first language in language classrooms. This research use experimental methods and to take the sample is use random sampling, The objective of the research includes 2 Indonesian EFL Lecturer and 48 Indonesian EFL students at first semester of teacher training education faculty in Banten Jaya University. The process to gate the data through the interview and questionnaires. The research finding had good result, indicated that English language give the positive response for the students. The result also emphasizing to the comprehension the meaning of English language.

Keyword: First language, students' responses, Indonesian EFL classroom
\end{abstract}

\section{INTRODUCTION}

It has always been a controversial issue to use the first language (L1) of the students in the foreign language (FL) classrooms. The L1 is perhaps the most useful and the least used resource students bring to the FL classrooms. This partly due some factors. The monolingual approach suggest that the target language ought to be the sole medium of communication, implying the prohibition of the native language would maximize the effectiveness of learning the target language. The theory and practice of established methods discourage the use of $\mathrm{L} 1$ in the foreign language (FL) classroom. Monolingual The first language (L1) is used by both the lecturer and learner in teaching and learning English. In English classrooms, that raises debatable and have two contrasting views. Using L1 in English Classrooms on one side is beneficial, and it has the advantages to support teaching and learning English. But on the other side in English Classrooms, the target language, interfere when the process of mastering. Buck (2001) in Khati (2011) defines the mother tongue is not easy. They argue that mother tongue. Those terms are difficult and controversial. As a result, the term is usually as synonymous. First 
language or mother tongue is a language learned before the people used the other language when they were children. Pokharel (2001) in Khati (2011), first language, mother tongue and native tongue are common terms for language which person acquires first in his childhood because it is spoken in the family and /or it is the language of the country where he is living. Some expert the advantages of the first language that can affect to students of English comprehension. Khati (2011) assumes that the people learning foreign language follow the same routes as they acquire their mother tongue, hence the use of the mother tongue in the learning process should be minimized. Furthermore, the uses of first language can the exposure the target language. Harmer (2009) also assumes that is restricts the students exposure to English. Thus, the lecturer should be monitoring the appropriate of the first language in the classrooms and the target of language learning can be optimal. In some cases, using first language in English classrooms, made beneficial to facilitating the language learning. Afzal, 2013: Schweers, 1999) argue that to show the judicious mother tongue or first language the classrooms did not reduce students exposure to English, but rather can assist and support the teaching and learning process.

Many experts believe that the several first languages also have several advantages in Indonesian EFL Classroom. Harmer (2009) mentions, (1) If lecturer want to discuss, interest, interact with their students, or ask to them what they want or need, they will get more detailed information from the lower-level students if they use L1 than if they use English; (2) translating English into the first language can also be a very good way of checking students understanding about the grammar points at the end of the lesson; (3) students (and their lecturer) can use the L1 to keep the social atmosphere of the class in good repair. In addition, according to Khati (2011), mother tongue can be used to provide a quick and accurate translation of an English word that might take several minutes for the lecturer to explain. Besides Schweers (1999) mentions, L1 is used to help them feel more comfortable and confident, to check comprehension and to define new vocabulary items. Furthermore, Alkinson (1987) also identifies the appropriate uses for the L1 in L2 classrooms as follow: eliciting language, checking comprehension, giving complex instruction to basic level, 
using translation to highlight a recently thought language item, checking for sense, testing, and developing circumlocution strategies. Relate with his, Auerbach (1993) lists the following uses for mother tongue: classrooms management, language analysis, presenting rules the govern grammar, discussing cross-cultural issues, giving instruction or prompts explaining errors, and checking for comprehension. It can be concluded that, the uses of first language during the learning activities in English classrooms have occasions, such as in classrooms discussion, explaining complex concepts and keeping classrooms atmosphere.

Munsey (2006) states application of science closely to the level of education attended by individual. The highest level of education is the level of University, where the individual in the period of emerging adulthood. Therefore, students need to adapt to these changes in order to solve the problems faced in their classrooms. Solimun and Rothblum in Ursia (2013) say that the tendency to not start immediately when faced with the task in an indication of delaying behavior and negligence in managing time and is an important factor that causes individuals to delay and completing task. Every individual of the student need the existence of selfresponses in order to achieve from other for achievement. One the indicator of achievement is the support of lecturer to work of the English task produce the expected four skill of English ability. As in Indonesian EFL Classrooms, the assignment given to students to use first language in Indonesian EFL Classrooms.

English as foreign Language (EFL) is being taught in mainstream university around the world. As part of a larger general material subject in Teacher Training Faculty, EFL lecturer have an opportunity to focus on aspects of learning beyond grammar, vocabulary, and the four skills. Too many times education focuses on what students don't know. Rarely do the lecturers have the opportunity to show the students how much they learned. Just as students learn the present simple, and move on to the present simple. Just as the students grasp past simple with regular verbs, the lecturer introduce them to irregular verb forms. Education focuses on what the students don't know. So, giving students a sense of achievement based on how much they have learned is important to raise students' response and confidence in their ability to learn more. 
Cole (1998) argues that the first language is very beneficial for beginner as these students have a little knowledge of the second language. The use of the first language can also present the main dissimilarities between the first language as the second language, to stimulate students and to decrease their anxiety. Furthermore, Cook (2008) point out that the lecturer of a second or foreign language can use the first language for two major purposes. Another important reason for using the first language by lecturer in the second language classroom is to create a natural relationship between lecturer and their students.

\section{B. METHODOLOGY}

The research method use quantitative research, where the researcher manipulate the variables treatments and then study the effect on the criterion variables (Kadir, 2015). This research is conducted to find out what occasions first language is used and the reason why is used by the lecturer and the students in Indonesian EFL Classrooms. The research samples were randomly selected. The total number of the students at semester VI of English education department at Banten Jaya University is 48 . The quantitative methods used to collect data about the Indonesian EFL students responses toward the use of first language in classroom and their reason for the first using the first language. The participant's English were 12 males and 36 females. Indonesian is used a mother tongue for these participants. A questionnaire was devised to gain insight into how lecturer evaluated their perception of the use the first language of the EFL learners in the classrooms. This questionnaire was sent out to nearly 2 lecturers at English Education Department. In addition, the interview with the lecturer and some students was used to reveal the reason why the students used first language in English classrooms. According to Miles and Hubberman in Sugiyono (2006) was used to analyzed the data, and it involve three steps, namely: (1) Data reduction, to sort the data related to the research problem by using categorization of the use of L1 in classrooms by Harmer (2009).

Data collection methods involved questioner and test. The purpose of the questionnaire was to obtain information about the use of the first language in the classrooms and students responses. With respect to questionnaire, the researcher talks to the students about the goal of the study. The questionnaire was distributed to the 
participant in class and they took fifteenth minute to finish it. The questionnaire was returned to the researcher at the same day and the return rate was $100 \%$ as the participant filled in the questionnaire in the presence of the researcher. To conducting the test, the researcher met the students and explains the objectives of the research to them. For the test too about 30 minutes and they were written test.

The data of the study were analyzed quantitatively using Statistical Package for the Social Sciences (SPSS version 16) to find out frequencies and percentages.

\section{FINDING AND DISCUSSION}

Based on the questionnaires and test result stated that the relationship between first language and Indonesian EFL classrooms were 0,315 with significance value $(>0,05)$, and students responses $0,024(<0,05)$. So, it can be mentioned it can be mentioned that the first language of student of English department directly influenced to Indonesian EFL classroom and their responses. Moreover, in this research the use in Indonesian EFL Classrooms. It is important to note that theoretically of English material in EFL classrooms, mention on the effect of the student use first language need to be optimized toward academic rather than nonacademic effort to improve student's responses in English Language ability. The finding of the next hypothesis provide reaffirmation of the importance of English EFL classrooms for students responses to their skills. There were several uses of the first language in English Classrooms and the data obtained from classrooms observation during the teaching and learning process.

\begin{tabular}{|l|l|l|}
\hline No & $\begin{array}{l}\text { The use of L1 by } \\
\text { the lecturer }\end{array}$ & $\begin{array}{l}\text { The use of } \\
\text { L1 by the } \\
\text { students }\end{array}$ \\
\hline 1 & $\begin{array}{l}\text { Giving the } \\
\text { instructions }\end{array}$ & $\begin{array}{l}\text { Building the } \\
\text { meaning with } \\
\text { group } \\
\text { discussion }\end{array}$ \\
\hline 2 & $\begin{array}{l}\text { Explains the } \\
\text { grammar point of } \\
\text { complex concept }\end{array}$ & $\begin{array}{l}\text { The } \\
\text { instruction } \\
\text { clarifying }\end{array}$ \\
\hline 3 & $\begin{array}{l}\text { New vocabulary } \\
\text { items defines }\end{array}$ & $\begin{array}{l}\text { The } \\
\text { pronunciation } \\
\text { clarifying }\end{array}$ \\
\hline 4 & $\begin{array}{l}\text { Students } \\
\text { comprehensions } \\
\text { checking }\end{array}$ & $\begin{array}{l}\text { The } \\
\text { frustration } \\
\text { Expressing }\end{array}$ \\
\hline 5 & $\begin{array}{l}\text { Keep } \\
\text { classrooms } \\
\text { atmosphere }\end{array}$ & \\
\hline
\end{tabular}


Table 1. The lecturer and students in English Classrooms uses L1

Khati, (2011) assumes that in order to carry out the task, the students must understand what they have to do. Thus the lecturer often used English first in giving the instruction, the when the students did not respond or understand it, they understand the instruction into the first language, to make the students understand about what they should do. Khati, (2011) states that most students felts that mother tongue should used to understand the difficult concept better. Khati, (2011) and Schweers (1999) claim that mother tongue or first language can be used to provide a quick and accurate translation of an English word.

Furthermore, Nation (2003) argue that a small amount of L1 can help overcome some of the obstacles. The students felt that is was easier to communicate, build a concept, share their ideas, and meaning by using first language. When the lecturer gave their instruction that they did not understand during the learning activities, they used L1 to clarify it by asking some questions to the lecturer related to the instruction. During speaking practice, the students also asked the lecturer about how to pronounce a word correctly. As a learning English is not easy mater, the students may face some obstacles during teaching and learning process, thus they used first language to show their frustration either to the lecturer or to their friends. Khati, (2011) states that using English only, in EFL classrooms can lead to some problems because there would be no guarantee that the instruction and explanation are understood correctly. Hence, by using first language they can express their frustrations and difficulties in learning English that should be considered by the lecturer to help them overcome the problems.

Beside those point mentioned above, the result of the interview which was conducted toward the English lecturer and the students at six semester revealed some responses about why the use first language in Indonesian EFL Classrooms.

\section{CONCLUSION}

This finding of the research included the lecturer views regarding the topic of the research. The finding of the present study is consistent with Lao' (2006) result .He stated some foreign language educators may consider translation as an important way to sure student's comprehension and important writing exercises. 
This research indicate that the lecturer and the students often used L1 is often used in several occasions, such as explaining complex concepts or grammar points, defining new vocabulary items, during group discussion to build meaning, checking students comprehension, keeping classification, clarifying instructions and pronunciations and students responses. Beside, there are some reason why the first language is used in Indonesian EFL classrooms. The lecturer use L1 because it is effective use to explaining the concept of grammar. Meanwhile, the students use L1, because they still lack to understand the material in English language. However, there some recommendation to reduce the excessive use L1 in EFL classrooms.

This research also indirectly shows that the students who use first language will delay their assignments in Indonesian EFL Classrooms, so will affect their English skill; furthermore there is a direct positive influence of students' responses to Indonesian EFL classrooms. This direct effect suggest that increasing responses improving students English ability. However, the finding of this research confirms that student's responses that must be optimized in the use first language, in order to improve students' academic English optimally.

Moreover, there is an indirect negative influence of students' responses on English language ability. In other word, it can be concluded that relationship between students' responses and first language. This related to the personality of a student is formed because of a Indonesian EFL Classroom. So, it assumed that students who has a low response is indirectly will not be motivated to get used to Indonesian language. Yet, English education students do not use first language with English language.

\section{REFERENCES}

Adikissnet. Konversi Nilai Kuantitatif ke dalam Nilai Kualititatif.

http://adikiss.net/2017/10/konversi-nilaiangka-kuantaJF61-itatif-ke-dalam: nilaihuruf-kualitatif-di-axcel/\# (diakses 29 Desember 2017).

Afzal, s. (2013). Using of the first language in English Classrooms as a way of scaffolding for both the students and teachers to learn and teach English. International research Journal of Applied and Basic sciences, 4(7), 1846-1854 
Atkinson, D. (1987). The mother tongue in the classroom: Neglected resources? ELT Journal, 8(1)2-5

Brown, H. Douglas. Language Assesment Principle and Classroom Practice. New York; Longman, 2004.

Creswell, John W. Educational Research; Planning, Conducting and Evaluating Quantitative and Qualitative Research. Pearson: University of Nebraska-Lincoln, 2010 .

Emzir. Metode Penelitian Pendidikan; Jakarta: Raja Gafindo Persada, 2010.

Gay, L.R. Mills Geoffrey E, and Airasian. Educational Research; Competencies for analysis and Applications, Colombus: Pearson, 2009.

Hadley, Alice Omaggio, Teaching Language in Context. Boston: Heile \& Heinie Publisher, 1993.

Harmer Jeremy. Practice of English Language Teaching. New York, Longman Group UK Limited, 1992.

Khati, Ashok Raj. (2011). When and why of Mother tongue Use in English Classrooms. Journal of NELTA,
Vol. 16 No. 1-2, Desember 2011: $42-51$

Khine, Mynt Swe. Teaching with Technology; Strategies for Enggaging Learners. Singapore; Pearson Prentice Hall, 2006.

Kumaravadivelu, B. Undersanding language Teaching; From Method to Postmethod. New Jersey; Lawrence Erlbaum Associates, 2008.

Richard, Jack C. dan Renandya Willy A. Methodology in Language Teaching; An Anthology of Current Practice. New York. Cambridge University Press. 2013.

Sharon, Smaldino E. Introduction Technology and Media for Learning. Colombus Ohio. Pearson Merril Prentice Hall, 2008.

Nation, Paul. (2003). The role of the first language in Foreign language Learning. Asian EFL Journal 5 (2), Sugiyono. 2015. Metode Pendekatan Kuantitatif, Kualtiatif, dan R\&D. Bandung: Alfabeta.

Tang, j. (2002). Using L1 in the English Classrooms English Teaching forum Journal 40 (1) January, 2002:34-36. 